\title{
Histone deacetylase inhibitors merged with protein tyrosine kinase inhibitors
}

\author{
Nan Zhou, Wenfang Xu* ${ }^{*}$ Yingjie Zhang* \\ College of Pharmacy, Shandong University, Ji'nan, Shandong, China.
}

\begin{abstract}
Summary Histone deacetylases (HDACs) are a family of metal enzymes which mainly regulates the acetylation level of histone, together with histone acetyl transferases (HATs). Recently, because many HDAC inhibitors (HDACis) have entered clinical trials for both solid and liquid tumors, HDACs are recognized as one of the promising targets for cancer treatment. The current trend is that more and more HDAC inhibitors are used in combination with other antitumor agents in order to optimize their effect and toxicity. Protein tyrosine kinases (PTKs) which play important roles in cellular signal transduction pathways and regulate series of physiological and biochemical processes, are another family of hot antitumor targets. This brief review will mainly talk about several reported chimeric HDACs-PTKs inhibitors.
\end{abstract}

Keywords: HDAC, PTKs, chimeric inhibitor

\section{Introduction}

Histone deacetylases (HDACs) are a class of proteases widely existing in eukaryotic cells. Up to now, there are 18 human HDACs that have been identified. On the basis of sequence similarity, intracellular localization and tissue specific distribution, human HDACs have been classified into 4 groups (1). Class I HDACs (HDAC1, 2, 3, and 8) located in the nucleus are expressed widely in various tissues and inhibit gene expression. Based on the sequence homology and domain organization, Class II HDACs are divided into two sub-groups, Class IIa (HDAC4, 5, 7, and 9) and Class IIb (HDAC6 and 10), and may be associated with cell differentiation $(2,3)$. Class IIa HDACs shuttle between the cytoplasm and nucleus; Class IIb HDACs situated in cytoplasm typically contain double zinc catalytic centers. Class IV HDAC (HDAC11) is comprised of a unique member HDAC11 just because of the specific structure of HDAC11 (4). In contrast to all of the above $\mathrm{Zn}^{2+}$ dependent HDACs, Class III (Sir1-7) homologous to the yeast Sir2 family of proteins are also called sirtuins $(2,3,5)$.

The nucleosome, which is the basic structural unit of eukaryotic chromosomes, consists of an octamer (an

*Address correspondence to:

Dr. Wenfang Xu and Dr. Yingjie Zhang, College of Pharmacy, Shandong University, 44 West Culture Road, Ji'nan 250012, Shandong, China.

E-mail: wenfxu@163.com (Xu WF); zhangyingjie@sdu.edu (Zhang YJ)
$\mathrm{H} 3-\mathrm{H} 4$ tetramer and two $\mathrm{H} 2 \mathrm{~A}-\mathrm{H} 2 \mathrm{~B}$ dimers) and DNA (deoxyribonucleic acid) wrapping around the octamer (6). It is the HDACs that catalyze the cleavage of the N-acetyl group from acetylated lysine residues located on the tails of the core nucleosomal histones (7). Together with the histone acetyl transferases, HDACs regulate the balance of acetylation and deacetylation (8). When HDACs are more active, histone proteins are deacetylated and bind tighter to DNA, thus it is difficult for transcriptional regulatory proteins to combine with DNA, leading to the inhibition of gene transcription (9). In addition to the regulation of histones, HDACs can also regulate the acetylation status of a variety of non-histone substrates, including key tumor suppressor proteins and proteins expressed by oncogenes (10).

Since vorinostat (SAHA) was approved by the US Food and Drug Administration (FDA) for cutaneous T-cell lymphoma in 2006, pharmaceutical chemists have paid increasing attention to HDACis (histone deacetylase inhibitors) in cancer therapy. According to the previous study, we easily find that almost all HDACis have the common pharmacophore, containing three domains. One is ZBG short for the zinc-binding group, such as hydroxamic acid. Another is a cap group, which is generally a hydrophobic and aromatic group. It is a saturated or unsaturated linker domain, composed of linear or cyclic structures that connects the ZBG and the cap group. According to their chemical structures, HDACis can be mainly divided into several classes, 
Table 1. Some typical clinical HDAC inhibitors

\begin{tabular}{|c|c|c|c|c|}
\hline Class & HDAC inhibitors & Structure & Clinical trials & Ref. \\
\hline \multirow[t]{4}{*}{ Hydroxamic acid } & $\begin{array}{l}\text { Vorinostat } \\
\text { (SAHA) }\end{array}$ & & Approved & (11) \\
\hline & $\begin{array}{l}\text { Panobinostat } \\
(\mathrm{LBH}-589)\end{array}$ & & Approved & $(12-15)$ \\
\hline & ITF2357 & & Phase II & (16) \\
\hline & SB939 & & Phase II & (17) \\
\hline Benzamide & $\begin{array}{l}\text { Entinostat } \\
\text { (MS-275) }\end{array}$ & & Phase II & (8) \\
\hline Carboxylic acid & Valproic acid & & Phase III & (18) \\
\hline Cyclic peptide & $\begin{array}{l}\text { Romidepsin } \\
\text { (FK228) }\end{array}$ & & Approved & (19) \\
\hline
\end{tabular}

PTKs $\left\{\begin{array}{l}\text { nRTKs: Abl, Src and so on. } \\ \text { RTKs: EGFR, FGFR, PDGFR, VEGFR and so on. }\end{array}\right.$

Figure 1. The family of PTKs and some typical members.

including hydroxamic acid, benzamide, carboxylic acid and cyclic peptides (Table 1).

Protein tyrosine kinases can catalyze the transfer of the $\gamma$-phosphoryl group on the ATP molecule to the tyrosine residues of substrate proteins, making them phosphorylated (16). The protein tyrosine kinase family with over 90 members is divided into two subfamilies, the receptor tyrosine kinases (RTKs) and the nonreceptor tyrosine kinases (nRTKs) (Figure 1) $(21,22)$. RTKs include EGFR (epidermal growth factor receptor), FGFR (fibroblast growth factor receptor), VEGFR (vascular endothelial growth factor receptor) and so on. nRTKs include Abl, Src and so on. FDA has already approved imatinib, gefitinib, erlotinib, sorafenib, sunitinib, dasatinib, nilotinib, laptinib, and pazopanib for clinical use (Table 2) (23). All of the RTKs are membrane proteins which consist of three parts: an extracellular ligand-binding domain, a transmembrane region and an intracellular kinase domain $(22,24)$. After a ligand binds to the extracellular domain, the receptors form dimers stimulating catalytic activity, then several tyrosine residues of the intracellular kinase domain become autophosphorylated. Only autophosphorylated RTKs can activate downstream signaling pathways.
Her (human epidermal growth factor receptor) has four subfamily-EGFR/Her1, Her2-4. EGFR is one typical target for kinase inhibitors in clinical trials. EGFR is a trans-membrane protein belonging to the HER-family of RTKs and can be activated by binding to EGF (epidermal growth factor), TGF-alpha (alphatransforming growth factor) and amphiregulin (34). The overexpression of both receptors and ligands may lead to uncontrolled activation of signal transduction pathways. However, Her2 has no soluble ligand, which is called an orphan receptor, and it is easier to form heterogeneous dimers with the other three family members. As Table 2 shows, gefitinib, erlotinib, and laptinib mainly target EGFR and Her2.

Numerous combinations of HDACis with other cytotoxic or targeted therapeutics have been tested in clinical trials (Table 3 ). There is no doubt that a synergistic effect really exists for inhibiting these two kinds of targets. For instance, a combination of SAHA and erlotinib cause a synergistic inhibition of cell growth. Tumor cells are potentially vulnerable to HDAC6 inhibition and this has been exploited by combining HDACi with proteosome inhibitors such as bortezomib. In addition, the combined effect of directly targeting oncogenic client proteins using imatinib and destabilizing Bcr-abl by HDACi has a potent antitumor effect in vitro. Moreover, the chemical flexibility of HDACis makes it possible to design multi-targeted small molecules. First of all, HDACis and EGFRis can be simply connected via a linker that can be cleaved under 
Table 2. Kinase inhibitors approved for use

\begin{tabular}{|c|c|c|c|c|}
\hline Generic name & Structure & U.S. FDA approved indications & Target kinases & Ref. \\
\hline $\begin{array}{l}\text { Imatinib } \\
(2001)\end{array}$ & & CML & $\begin{array}{l}\text { Abl, c-Kit, } \\
\text { PDGFRa, PDGFRb }\end{array}$ & $(25)$ \\
\hline $\begin{array}{l}\text { Gefitinib } \\
(2003)\end{array}$ & & NSCLC & EGFR & $(26)$ \\
\hline Erlotinib & & NSCLC, pancreatic cancers & EGFR & $(27)$ \\
\hline $\begin{array}{l}\text { Sorafenib } \\
(2005)\end{array}$ & & $\begin{array}{l}\text { Hepatocellular carcinoma, } \\
\text { renal cell carcinoma }\end{array}$ & $\begin{array}{l}\text { Raf, VEGFR2, } \\
\text { VEGFR3, c-Kit, PDGFRb }\end{array}$ & $(28)$ \\
\hline $\begin{array}{l}\text { Sunitinib } \\
(2006)\end{array}$ & & $\begin{array}{l}\text { GIST, } \\
\text { renal cell carcinoma }\end{array}$ & $\begin{array}{l}\text { c-Kit, VEGFR, } \\
\text { PDGFR, FLT3 }\end{array}$ & $(29)$ \\
\hline $\begin{array}{l}\text { Dasatinib } \\
(2006)\end{array}$ & & CML & Abl, c-Kit, PDGFR, Src & $(30)$ \\
\hline $\begin{array}{l}\text { Nilotinib } \\
(2007)\end{array}$ & & CML & $\begin{array}{l}\text { Abl, c-Kit, PDGFRb, } \\
\text { Src, Ephthrin }\end{array}$ & $(31)$ \\
\hline $\begin{array}{l}\text { Laptinib } \\
(2007)\end{array}$ & & Breast cancer & EGFR, Her-2 & (32) \\
\hline $\begin{array}{l}\text { Pazopanib } \\
\text { (2009) }\end{array}$ & & Kidney cancer & VEGFR & (33) \\
\hline
\end{tabular}

Table 3. Active clinical trials using HDACi in combination with Protein Tyrosine Kinase Inhibitors

\begin{tabular}{lccl}
\hline HDACi & Phase & Combination drug & Indication \\
\hline SAHA & II & Bortezomib & Recurrent glioblastoma multiforme \\
SAHA & II & Bortezomib & Recurrent lymphoma \\
SAHA & II & Bortezomib & Refractory multiple myeloma \\
SAHA & III & Bortezomib & Multiple myeloma \\
LBH589 & I & Bortezomib & Multiple myeloma \\
Depsipeptide & I/II & Bortezomib & Multiple myeloma \\
Depsipeptide & II & Bortezomib & Multiple myeloma \\
PXD101 & I & Bortezomib & Advanced solid tumors, lymphomas \\
\hline
\end{tabular}

physiological conditions. In addition, without interfering each other, two individual moieties can be joined through a stable spacer allowing interaction with their proposed targets. Third, two pharmacophores can lead to a single compound whose fragments attack the desired targets without interference. Thus, it is rational to target both histone deacetylase and protein tyrosine kinase.

\section{Examples of multi-targeting HDACis}

CUDC-101 is one successful example in clinical phase I $(35,36)$. Cai et al. used a suitable linker to connect the known EGFR/Her2 inhibitor quinazoline with the known HDAC inhibitor hydroxamic acid. They synthesized a series of compounds with CUDC-101 as 
Table 4. The compounds Cai et al. designed

\begin{tabular}{|c|c|c|c|c|c|c|c|}
\hline Compound & $\mathrm{X}$ & Y & Z & $\mathrm{n}$ & $\mathrm{R}_{1}$ & $\mathrm{R}_{2}$ & $\mathrm{R}_{3}$ \\
\hline 1 & $\mathrm{O}$ & $\mathrm{CH}_{2}$ & direct & 1 & $\mathrm{~F}$ & $\mathrm{Cl}$ & $\mathrm{OCH}_{3}$ \\
\hline 2 & $\mathrm{O}$ & $\mathrm{CH}_{2}$ & direct & 2 & F & $\mathrm{Cl}$ & $\mathrm{OCH}_{3}$ \\
\hline 3 & $\mathrm{O}$ & $\mathrm{CH}_{2}$ & direct & 3 & $\mathrm{~F}$ & $\mathrm{Cl}$ & $\mathrm{OCH}_{3}$ \\
\hline 4 & $\mathrm{O}$ & $\mathrm{CH}_{2}$ & direct & 3 & $\mathrm{H}$ & $\mathrm{C} \equiv \mathrm{CH}$ & $\mathrm{OCH}_{3}$ \\
\hline 5 & $\mathrm{O}$ & $\mathrm{CH}_{2}$ & direct & 4 & $\mathrm{~F}$ & $\mathrm{Cl}$ & $\mathrm{OCH}_{3}$ \\
\hline 6 & $\mathrm{O}$ & $\mathrm{CH}_{2}$ & direct & 4 & $\mathrm{H}$ & $\mathrm{C} \equiv \mathrm{CH}$ & $\mathrm{OCH}_{3}$ \\
\hline 7 & $\mathrm{O}$ & $\mathrm{CH}_{2}$ & direct & 5 & $\mathrm{~F}$ & $\mathrm{Cl}$ & $\mathrm{OCH}_{3}$ \\
\hline 8 CUDC-101 & $\mathrm{O}$ & $\mathrm{CH}_{2}$ & direct & 5 & $\mathrm{H}$ & $\mathrm{C} \equiv \mathrm{CH}$ & $\mathrm{OCH}_{3}$ \\
\hline 9 & $\mathrm{O}$ & $\mathrm{CH}_{2}$ & direct & 5 & F & $\mathrm{C} \equiv \mathrm{CH}$ & $\mathrm{OCH}_{3}$ \\
\hline 10 & $\mathrm{O}$ & $\mathrm{CH}_{2}$ & direct & 5 & & $\mathrm{Cl}$ & $\mathrm{OCH}_{3}$ \\
\hline 11 & $\mathrm{O}$ & $\mathrm{CH}_{2}$ & direct & 5 & $\mathrm{~F}$ & $\mathrm{Cl}$ & $\mathrm{H}$ \\
\hline 12 & $\mathrm{O}$ & $\mathrm{CH}_{2}$ & direct & 5 & F & $\mathrm{Cl}$ & $\mathrm{CH}_{2} \mathrm{CH}_{2} \mathrm{OCH}_{3}$ \\
\hline 13 & $\mathrm{NH}$ & $\mathrm{C}=\mathrm{O}$ & direct & 6 & F & $\mathrm{Cl}$ & $\mathrm{OCH}_{3}$ \\
\hline 14 & S & $\mathrm{CH}_{2}$ & direct & 5 & $\mathrm{~F}$ & $\mathrm{Cl}$ & $\mathrm{OCH}_{3}$ \\
\hline 15 & $\mathrm{~S}(\mathrm{O})_{2}$ & $\mathrm{CH}_{2}$ & direct & 5 & $\mathrm{~F}$ & $\mathrm{Cl}$ & $\mathrm{OCH}_{3}$ \\
\hline 16 & $\mathrm{O}$ & $\mathrm{CH}_{2}$ & $\mathrm{CH}_{2}$ & 5 & $\mathrm{~F}$ & $\mathrm{Cl}$ & $\mathrm{OCH}_{3}$ \\
\hline 17 & $\mathrm{O}$ & $\mathrm{CH}_{2}$ & $\mathrm{CH}_{2}$ & 5 & $\mathrm{H}$ & $\mathrm{H}$ & $\mathrm{OCH}_{3}$ \\
\hline 18 & $\mathrm{O}$ & $\mathrm{CH}_{2}$ & $\mathrm{CH}_{2}$ & 5 & $\mathrm{~F}$ & $\mathrm{H}$ & $\mathrm{OCH}_{3}$ \\
\hline 19 & $\mathrm{O}$ & $\mathrm{CH}_{2}$ & (S)- $\mathrm{CHCH} 3$ & 5 & $\mathrm{H}$ & $\mathrm{H}$ & $\mathrm{OCH}_{3}$ \\
\hline 20 & $\mathrm{O}$ & $\mathrm{CH}_{2}$ & (R)- $\mathrm{CHCH} 3$ & 5 & $\mathrm{H}$ & $\mathrm{H}$ & $\mathrm{OCH}_{3}$ \\
\hline 21 & $\mathrm{O}$ & $\mathrm{CH}_{2}$ & (R)- $\mathrm{CHCH} 3$ & 5 & $\mathrm{~F}$ & $\mathrm{H}$ & $\mathrm{OCH}_{3}$ \\
\hline 22 & $\mathrm{O}$ & $\mathrm{CH}_{2}$ & (R)- $\mathrm{CHCH} 3$ & 5 & $\mathrm{Cl}$ & $\mathrm{H}$ & $\mathrm{OCH}_{3}$ \\
\hline 23 & $\mathrm{O}$ & $\mathrm{CH}_{2}$ & direct & 5 & $\mathrm{~F}$ & $\mathrm{Cl}$ & $\mathrm{OCH}_{3}$ \\
\hline 24 & $\mathrm{O}$ & $\mathrm{CH}_{2}$ & direct & 5 & $\mathrm{H}$ & $\mathrm{C} \equiv \mathrm{CH}$ & $\mathrm{OCH}_{3}$ \\
\hline
\end{tabular}

a potent candidate (Table 4 ).

To investigate structure activity relationships, compounds were evaluated in EGFR/Her2 kinase and HDAC enzyme assays. The data showed with an increased carbon chain length, HDAC inhibitory activity increased and the optimal length was six. Apparently, the length of the hydroxamic acid side chain was important for HDAC inhibition. Phenyl ring substitutions almost had no effect on HDAC inhibition activity, but larger ones such as compound $\mathbf{1 0}$ showed decreased activity. However, the carbon chain length and phenyl ring substitutions were not critical factors that affected EGFR/Her2 activity. Taking the influence of C-7 substitutions into consideration, they chose six carbons as the linker and synthesized compounds 7 , 11, 12. When $\mathrm{X}$ is $\mathrm{O}$, it was amazing that on one hand, there was no apparent differences for inhibiting HDAC, on the other hand, as for EGFR/Her2 inhibition, $\mathrm{OCH}_{3}$ was superior to $\mathrm{CH}_{2} \mathrm{CH}_{2} \mathrm{OCH}_{3}$, which was more efficient than $\mathrm{H}$. Then fixing $\mathrm{OCH}_{3}$ as $\mathrm{R}_{3}, 7, \mathbf{1 3}, \mathbf{1 4}, 15$ were compared. $7(\mathrm{X}=\mathrm{O})$ showed outstanding HDAC inhibition. However, it was a pity that rarely could we tell 7, 13, 14 apart only according to EGFR/Her2 inhibition, indicating that either, sulfide and amide may not be critical. The conjugation of the quinazoline ring with the phenyl ring was disrupted when the length between them was longer. Only compound 17 ( $\mathrm{Z}=$ $\left.\mathrm{CH}_{2}, \mathrm{R}_{1}=\mathrm{H}, \mathrm{R}_{2}=\mathrm{H}\right)$ and $\mathbf{1 8}\left(\mathrm{Z}=\mathrm{CH}_{2}, \mathrm{R}_{1}=\mathrm{F}, \mathrm{R}_{2}=\mathrm{H}\right)$ were promising on HDAC inhibition. With regard to EGFR/Her2 inhibition, all compounds were inferior to 7. In brief, the changing of an aniline to a benzylamine resulted in less potent compounds. Supposing that the hydroxamic acid side chain position may have an effect on inhibitory activities, $\mathbf{2 3}$ and $\mathbf{2 4}$ were synthesized and behaved less potently. In conclusion, $\mathbf{7}$ and $\mathbf{8}$ were better HDAC, EGFR and Her2 inhibitors. From these conditions, they further evaluated these two compounds against several cancer cell lines, such as NSCLC (nonsmall-cell lung cancer), liver, breast and pancreatic cancer cell lines. Compared with positive control compounds-vorinostat, erlotinib, lapatinib, the combination of vorinostat and erlotinib, and the combination of vorinostat and lapatinib, it is stirring that $\mathbf{8}$ behaved much better or at least equally (35).

Cheng-Jung Lai et al. continued to study the antiproliferative effects of $\mathbf{8}$. They tested the inhibition of HDAC, EGFR and Her2 enzyme activities, indicating nearly the same result. Additionally, by exposing cells to different concentrations of CUDC-101 for 5-24 h, they evaluated the effects in cancer cell lines. Fortunately, 
Table 5. The compounds depending on laptinib which Siavosh Mahboobi et al. designed

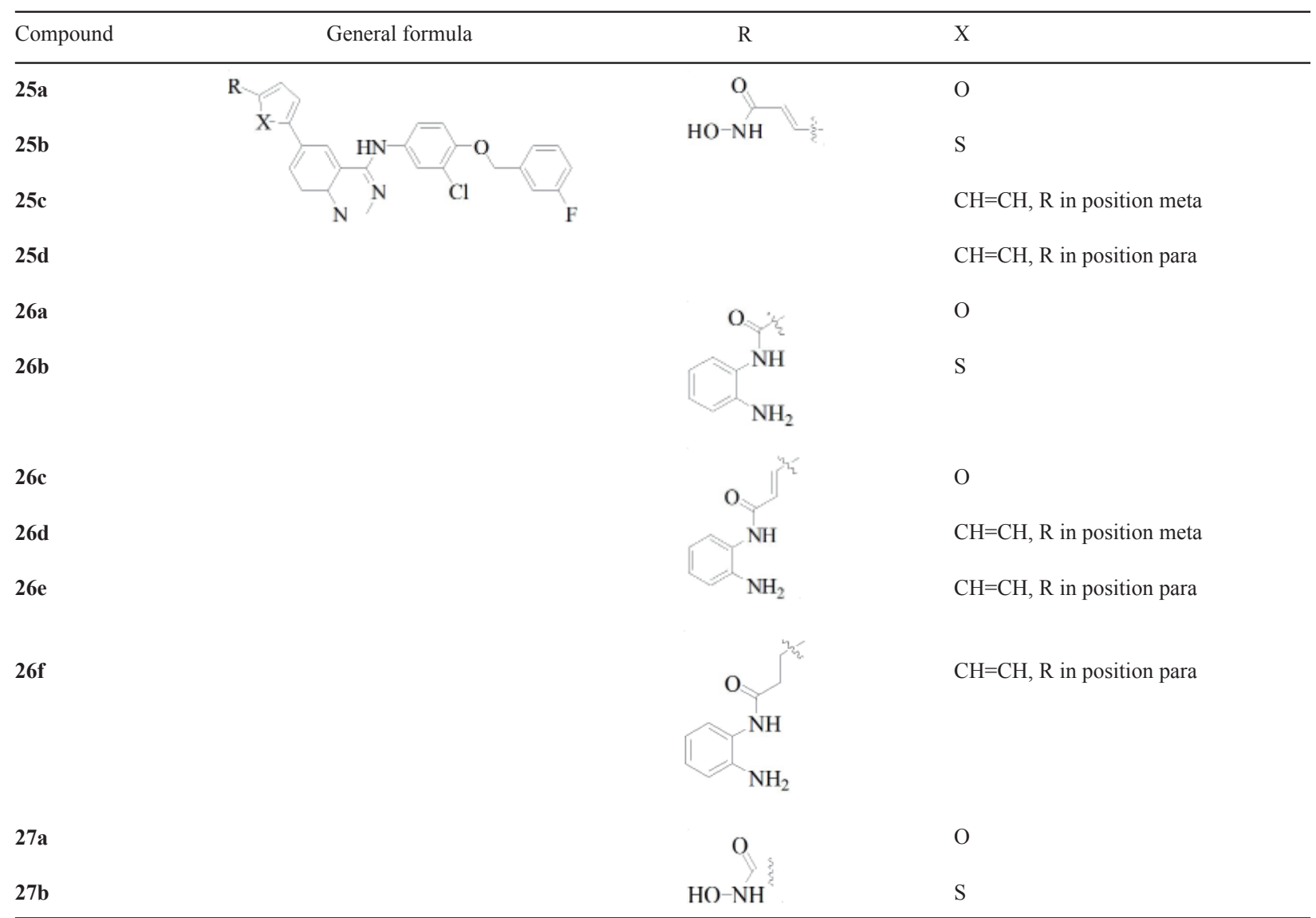

CUDC-101 could increase the acetylation of not only histone $\mathrm{H} 3$ and $\mathrm{H} 4$ but also non-histone substrates such as p53 and a-tubulin, and inhibit the autophosphorylation of EGFR and Her2. This result made it clear that CUDC101 really targeted HDAC, EGFR, and Her2. The data of growth inhibition in vitro matched what Cai et al. observed. It was encouraging that CUDC-101 displayed a broad activity in vivo xenograft models. In mouse xenograft models, CUDC-101 induced 30\% tumor regression and did better than positive control compound erlotinib at a maximum tolerated dose and vorinostat at an equimolar concentration (36).

In short, in view of its potent drug-like properties and safety, CUDC-101 has already been selected for clinical development. Siavosh Mahboobi et al. designed and synthesized another series of histone deacetylase inhibitors merged with protein tyrosine kinase inhibitors depending on the compound laptinib. SAHA a hydroxamic acid-based HDAC inhibitor has already been approved and MS-275 as a benzamide-HDAC inhibitor has been in phase II clinical trial (Table 1), so hydroxamic acid and benzamide were chosen to chelate the $\mathrm{Zn}^{2+}$. They also changed the substitution patterns from meta to para, altered bioisosteres and explored the effect on the system of vinylogous (Table 5).

In biochemical, cellular and target-specific assays, they concluded several points. First, hydroxamic acid displayed more potent HDAC inhibition, meanwhile, hydroxamic acid or benzamide were insignificant for EGFR/Her2 inhibition. Second, for HDAC inhibition, bioisosteres and vinylogous were of prime importance and meta surpassed pera. The fact that almost all of the compounds behaved no better than SAHA really depressed everyone. On the contrary, even though bioisosteres, vinylogous and substitution patterns had nothing to do with EGFR/Her2 inhibition, compared to laptinib, each compound showed expectant ability for inhibiting EGFR/Her2. In addition, they also investigated cytotoxicity of these compounds towards some selected cancer cell lines and found that 25a and 25c were the most potential chimeric inhibitors (37). From these preclinical data, some improvements could be seen noticeably, but HDAC inhibition activity was far from satisfactory. More effort should be made for further development.

Based on the compound imatinib, Siavosh Mahboobi et al. designed and synthesized another series of histone deacetylase inhibitors (Table 6). In vitro data, benzamide almost showed no HDAC6 inhibition and benzamide was outstripped by hydroxamic acid in inhibiting HDAC1. All the designed compounds were exciting because of their potent inhibition of HDAC. On the contrary, their inhibition of Abl kinase in comparison with imatinib was just passable. The introduction of cellular histone $\mathrm{H} 3 \mathrm{~K}(\mathrm{Ac})$ hyperacetylation and cytotoxicity towards HeLa (henrietta lacks strain of 
Table 6. The compounds depending on imatinib which Siavosh Mahboobi et al. designed

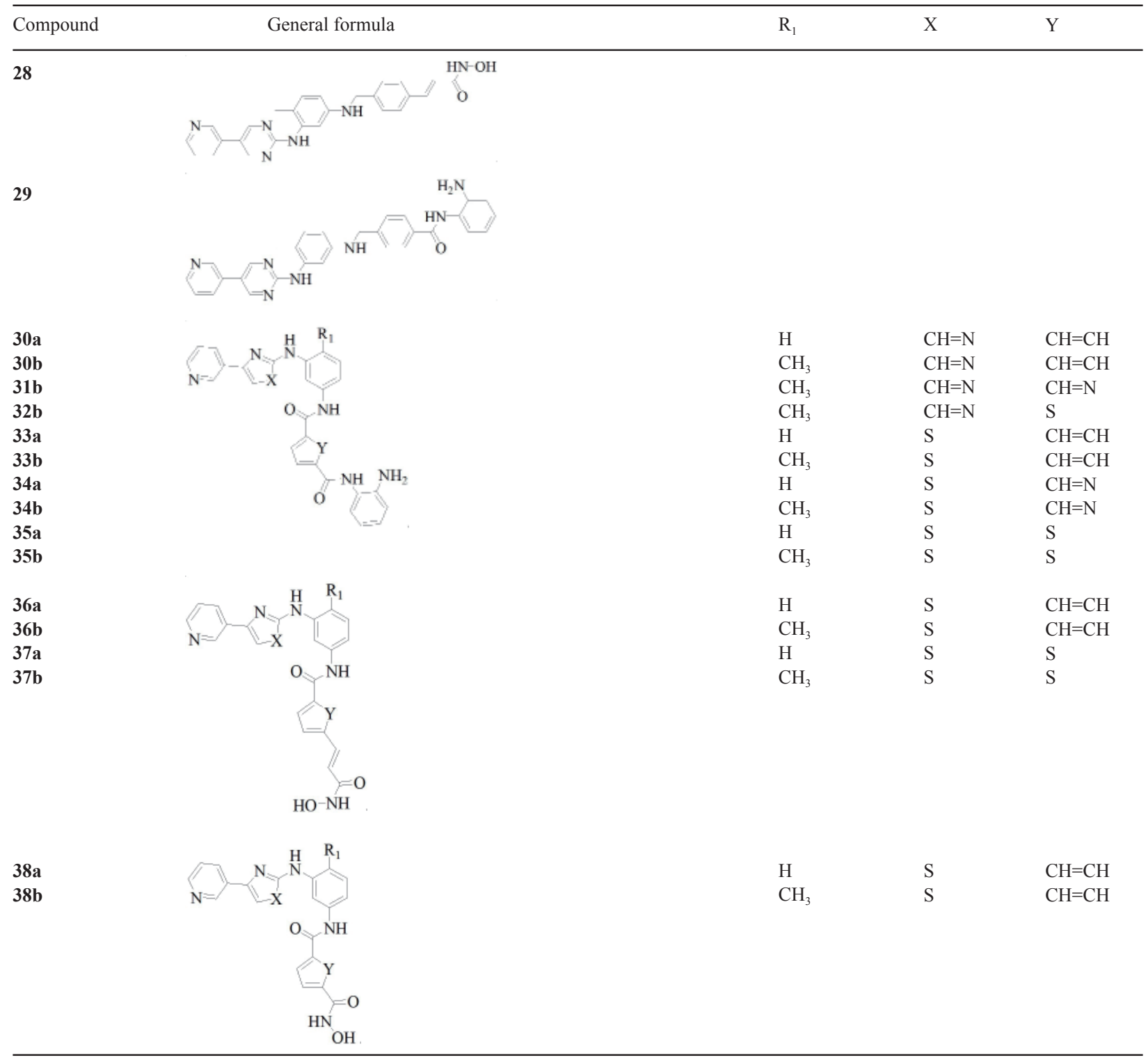

cancer cells) and K562 cells were used to estimate the cellular efficacy. All HDAC1 inhibitors had a potency of inducing histone $\mathrm{H} 3$ hyperacetylation in HeLa cells. In addition, the cytotoxicity of these analogues towards HeLa and K562 cells was in low micromolar or submicromolar range, nevertheless, the potency of imatinib towards K562 cells was superior to that of all designed compounds. Replacing the amine structure with amide resulted in reduced activity. In addition, introduction of a heterocycle decreased Abl kinase inhibition. From the benzene derivatives to pyridine and thiophene derivatives the HDAC1 inhibitory potency decreased. Although $\mathbf{3 0 b}$, 32b, and 36b showed potent HDAC inhibition, their inhibition of Abl kinase was low grade compared with imatinib (38).

Miao Zuo et al. synthesized N-aryl salicylamides as novel HDAC-EGFR dual inhibitors (Table 7). As is known, the length of the hydroxamic acid chain is a key factor for EGFR and HDAC inhibition and the optimal length is six or five. From the data of inhibition activities against EGFR, 39b, 39h, 39i, 39l, 39k, and 39o had strenuous inhibition activities, and the following 4 points were easily found. Comparing 39f, 39m, and 39n, 39f behaved much better just because of the construction of a pseudo six-membered ring. And 39n played no important role. Moreover, it was favorable when $\mathrm{R}_{2}$ was a methoxy group. Comparing 390 with 39f, there was no doubt that an ether linker was much better than an amide linker, which was also applied to HDAC inhibition. As for HDAC inhibition, it was found that only compound 39n was superior to SAHA. Thus the substitution on the N-phenyl was not vital. The antiproliferative activities were evaluated against human cancer cell lines A431, A549, and HL-60. 39o did best against A431 and A549. At the same time, 39k and 39n exhibited higher potency against HL-60. All in all, N-aryl saliylamides with a hydroxamic acid moiety at the 5-position were promising as HDAC-EGFR dual inhibitors (39).

Based on erlotinib, Thomas Beckers et al. designed a new series of dual-selective inhibitors (Table 8). They 
Table 7. The compounds which Miao Zuo et al. synthesized

\begin{tabular}{|c|c|c|c|c|c|}
\hline Compound & General formula & $\mathrm{n}$ & $\mathrm{R}_{1}$ & $\mathrm{R}_{2}$ & $\mathrm{R}_{3}$ \\
\hline $\begin{array}{l}39 \mathrm{a} \\
39 \mathrm{~b} \\
39 \mathrm{c} \\
39 \mathrm{~d} \\
39 \mathrm{e} \\
39 \mathrm{f} \\
39 \mathrm{~g} \\
39 \mathrm{~h} \\
39 \mathrm{i} \\
39 \mathrm{j} \\
39 \mathrm{k} \\
39 \mathrm{l} \\
39 \mathrm{~m} \\
39 \mathrm{n}\end{array}$ & $\mathrm{O}_{\mathrm{R}}$ & $\begin{array}{l}5 \\
5 \\
5 \\
5 \\
5 \\
5 \\
5 \\
5 \\
5 \\
6 \\
5 \\
5 \\
5 \\
5\end{array}$ & $\begin{array}{l}\mathrm{H} \\
3-\mathrm{F} \\
3,4-\mathrm{diF} \\
3-\mathrm{Cl}-4-\mathrm{F} \\
3-\mathrm{CF}_{3} \\
3-\mathrm{C} \equiv \mathrm{CH} \\
3,4-\mathrm{diCl} \\
3-\mathrm{CF} 3-4-\mathrm{Cl} \\
3-\mathrm{Cl}-4-(3-\mathrm{FBnO}) \\
3-\mathrm{C} \equiv \mathrm{CH} \\
3-\mathrm{Cl}-4-\mathrm{F} \\
3-\mathrm{C} \equiv \mathrm{CH} \\
3-\mathrm{C} \equiv \mathrm{CH} \\
3-\mathrm{C} \equiv \mathrm{CH}\end{array}$ & $\begin{array}{l}\mathrm{H} \\
\mathrm{H} \\
\mathrm{H} \\
\mathrm{H} \\
\mathrm{H} \\
\mathrm{H} \\
\mathrm{H} \\
\mathrm{H} \\
\mathrm{H} \\
\mathrm{H} \\
\mathrm{OCH}_{3} \\
\mathrm{OCH}_{3} \\
\mathrm{H} \\
\mathrm{H}\end{array}$ & $\begin{array}{l}\mathrm{OH} \\
\mathrm{OH} \\
\mathrm{OH} \\
\mathrm{OH} \\
\mathrm{OH} \\
\mathrm{OH} \\
\mathrm{OH} \\
\mathrm{OH} \\
\mathrm{OH} \\
\mathrm{OH} \\
\mathrm{OH} \\
\mathrm{OH} \\
\mathrm{H} \\
\mathrm{OCH}_{3}\end{array}$ \\
\hline 390 & & & & & \\
\hline
\end{tabular}

Table 8. The compounds which Miao Zuo et al. synthesized

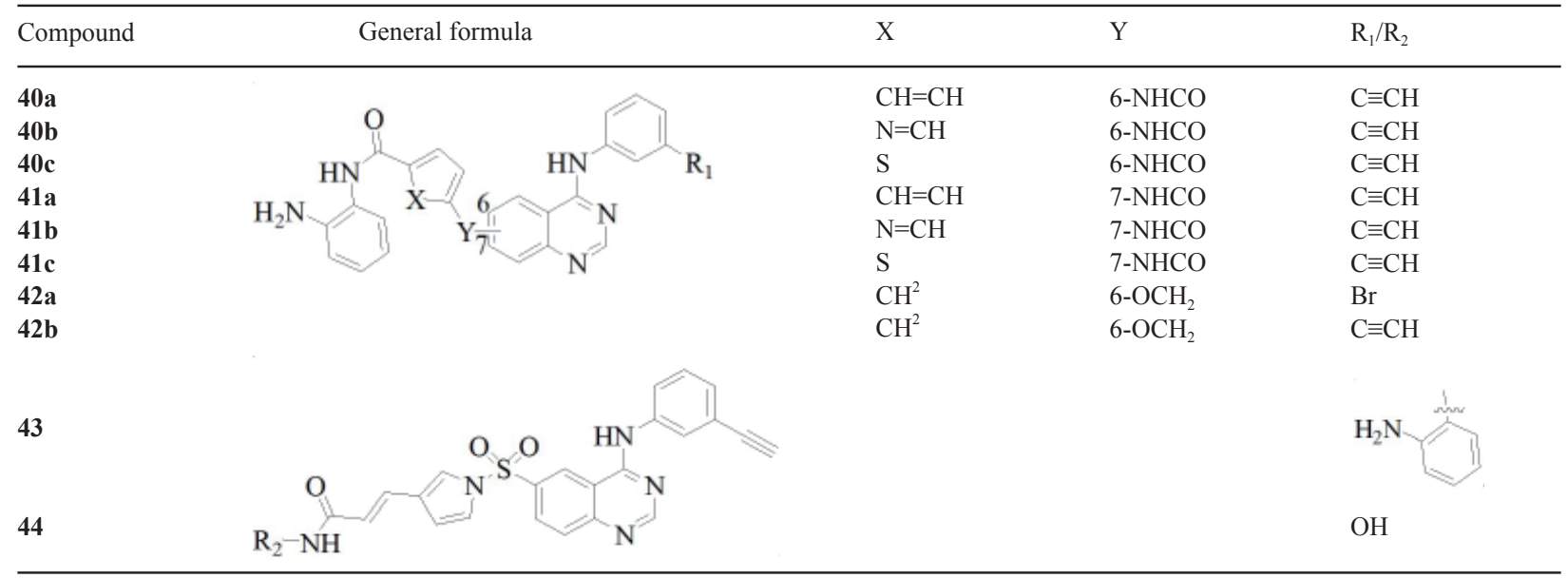

tested the inhibition of nuclear extract, cell HDAC and rHDAC1, rHDAC3, rHDAC6 and rHDAC8. 40ac had no significant inhibition of HDAC. However, 41a-c with substitution at the 7-position achieved a better performance. Compared to SAHA, 41a-c were far from satisfactory. $\mathbf{4 2 a}$ and $\mathbf{4 2 b}$ almost had the same inhibition, showing that exchange of the ethyl group with bromine made no difference. As for $\mathbf{4 3}$ and $\mathbf{4 4 ,}$ they behaved better and $\mathbf{4 4}$ was a great surprise to us with a lower nanomolar inhibition.

In view of HDAC inhibition, only $\mathbf{4 2 a}, \mathbf{4 2} \mathbf{b}, \mathbf{4 3}$, and 44 were tested for inhibition of EGFR and Her-2 kinase activity. To some extent, all of them inhibited EGFR and HER2, and 42a, 42b, and erlotinib were almost at the same level. Unfortunately, the selectivity profile towards EGFR/Her1 and Her2 did not obviously change.

With regard to cytotoxicity, $42 \mathrm{a}, \mathbf{4 2 b}, \mathbf{4 3}$, and 44 showed profound activity towards A549 NSCLS cells with 44 being the most promising dual inhibitor (40).

Xuan Zhang et al. designed other dual-targeted inhibitors (Table 9). Owing to the hydroxamic acid being a potent zinc binding group, 45a, 45b, 46a, and 46b with carboxylic acids showed no HDAC inhibition. The ZBG (zinc binding group) location played an important role in unsaturated hydroxamates, while it had no influence on the saturated ones. 48a was the best HDAC inhibitor.

Unfortunately, all the compounds were inferior to lapatinib on EGFR inhibition and Her2 inhibition, suggesting that hydroxamate on the phenyl group negatively affected PTK inhibition. Thus lipophilic ZBG might be worthy of investigation (41).

\section{Conclusions}

Recently, HDACis have been recognized as a promising 
Table 9. The compounds which Xuan Zhang et al. synthesized

\begin{tabular}{|c|c|c|c|c|}
\hline Compound & General formula & $\mathrm{R}_{1}$ & $\mathrm{R}_{2}$ & $\mathrm{R}_{3}$ \\
\hline $45 \mathrm{a}$ & & & $\mathrm{CH}_{3}$ & $\mathrm{OH}_{\mathrm{OH}}$ \\
\hline $45 b$ & & $\mathrm{CH}_{3} \mathrm{OCH}_{2} \mathrm{CH}_{2}$ & $\mathrm{CH}_{3} \mathrm{OCH}_{2} \mathrm{CH}_{2}$ & para \\
\hline $46 a$ & & & $\mathrm{CH}_{3}$ & meta \\
\hline $46 b$ & & $\mathrm{CH}_{3} \mathrm{OCH}_{2} \mathrm{CH}_{2}$ & $\mathrm{CH}_{3} \mathrm{OCH}_{2} \mathrm{CH}_{2}$ & meta $\mathrm{OH}$ \\
\hline $47 a$ & & & $\mathrm{CH}_{3}$ & para $-\mathrm{HN}^{-\mathrm{OH}}$ \\
\hline $47 b$ & & $\mathrm{CH}_{3} \mathrm{OCH}_{2} \mathrm{CH}_{2}$ & $\mathrm{CH}_{3} \mathrm{OCH}_{2} \mathrm{CH}_{2}$ & para $-\overbrace{\mathrm{HN}-\mathrm{OH}}^{\mathrm{O}}$ \\
\hline $48 \mathrm{a}$ & & & $\mathrm{CH}_{3}$ & $\overbrace{\mathrm{HN}-\mathrm{OH}}^{\mathrm{O}}$ \\
\hline $48 b$ & & $\mathrm{CH}_{3} \mathrm{OCH}_{2} \mathrm{CH}_{2}$ & $\mathrm{CH}_{3} \mathrm{OCH}_{2} \mathrm{CH}_{2}$ & $\overbrace{\mathrm{HN}-\mathrm{OH}}^{\mathrm{O}}$ \\
\hline $49 a$ & & & $\mathrm{CH}_{3}$ & meta- $\mathrm{HN}-\mathrm{OH}$ \\
\hline 49b & & $\mathrm{CH}_{3} \mathrm{OCH}_{2} \mathrm{CH}_{2}$ & $\mathrm{CH}_{3} \mathrm{OCH}_{2} \mathrm{CH}_{2}$ & meta- $\overbrace{\mathrm{HN}-\mathrm{OH}}^{\mathrm{O}}$ \\
\hline $50 a$ & & & $\mathrm{CH}_{3}$ & meta ${ }_{\mathrm{HN}-\mathrm{OH}}^{\mathrm{O}}$ \\
\hline $50 \mathrm{~b}$ & & $\mathrm{CH}_{3} \mathrm{OCH}_{2} \mathrm{CH}_{2}$ & $\mathrm{CH}_{3} \mathrm{OCH}_{2} \mathrm{CH}_{2}$ & meta $\overbrace{\mathrm{HN}-\mathrm{OH}}^{\mathrm{O}}$ \\
\hline
\end{tabular}

class of anticancer therapeutics and many chimeric HDACis have been synthesized, including inhibitors merged with protein tyrosine kinase inhibitors. Their chemical flexibility made it possible that HDACis can bind to multi-targets. However, when contrasted to the comparable compound which aims at one of the targets, the chimeric HDACis may have a disadvantage that they are less potent. Besides, more clinical studies are needed to decide whether they can combat drug resistance. In a word, such studies encourage people to do more on HDAC inhibitors merged with protein tyrosine kinase inhibitors.

\section{References}

1. Gregoretti IV, Lee YM, Goodson HV. Molecular evolution of the histone deacetylase family: Functional implications of phylogenetic analysis. J Mol Biol. 2004; 338:17-31.

2. Lin HY, Chen CS, Lin S, Weng JR, Chen CS. Targeting histone deacetylase in cancer therapy. Med Res Rev. 2006; 26:397-413.

3. Gray SG, Ekstrom TJ. The human histone deacetylase family. Exp Cell Res. 2001; 262:75-83.

4. Gao L, Cueto MA, Asselbergs F, Atadja P. Cloning and functional characterization of HDAC11, a novel member of the human histone deacetylase family. J Biol Chem. 2002; 277:25748-25755.

5. Witt O, Deubzer HE, Milde T, Oehme I. HDAC family: What are the cancer relevant targets? Cancer Lett. 2009; 277:8-21.

6. Drummond DC, Noble CO, Kirpotin DB, Guo Z, Scott GK, Benz CC. Clinical development of histone deacetylase inhibitors as anticancer agents. Annu Rev
Pharmacol Toxicol. 2005; 45:495-528.

7. Methot JL, Chakravarty PK, Chenard M, et al. Exploration of the internal cavity of histone deacetylase (HDAC) with selective HDAC1/HDAC2 inhibitors (SHI-1:2). Bioorg Med Chem Lett. 2008; 18:973-978.

8. Jona A, Khaskhely N, Buglio D, Shafer JA, Derenzini E, Bollard CM, Medeiros LJ, Illes A, Ji Y, Younes A. The histone deacetylase inhibitor entinostat (SNDX275) induces apoptosis in Hodgkin lymphoma cells and synergizes with Bcl-2 family inhibitors. Exp Hematol. 2011; 39:1007-1017.

9. Huang WJ, Chen CC, Chao SW, Yu CC, Yang CY, Guh JH, Lin YC, Kuo CI, Yang P, Chang CI. Synthesis and evaluation of aliphatic-chain hydroxamates capped with osthole derivatives as histone deacetylase inhibitors. Eur J Med Chem. 2011; 46:4042-4049.

10. New M, Olzscha H, La Thangue NB. HDAC inhibitorbased therapies: Can we interpret the code? Mol Oncol. 2012; 6:637-656.

11. Marks PA, Breslow R. Dimethyl sulfoxide to vorinostat: Development of this histone deacetylase inhibitor as an anticancer drug. Nat Biotechnol. 2007; 25:84-90.

12. Qian DZ, Kato Y, Shabbeer S, Wei Y, Verheul HM, Salumbides B, Sanni T, Atadja P, Pili R. Inhibitors: The hydroxamic acid derivative LBH589 targeting tumor angiogenesis with histone deacetylase. Clin Cancer Res. 2006; 12:634-642.

13. Budman DR, Tai J, Calabro A, John V. The histone deacetylase inhibitor panobinostat demonstrates marked synergy with conventional chemotherapeutic agents in human ovarian cancer cell lines. Invest New Drugs. 2010; 29:1224-1229.

14. Strickler JH, Starodub AN, Jia J, Meadows KL, Nixon AB, Dellinger A, Morse MA, Uronis HE, Marcom PK, Zafar SY, Haley ST, Hurwitz HI. Phase I study of bevacizumab, everolimus, and panobinostat (LBH-589) 
in advanced solid tumors. Cancer Chemother Pharmacol. 2012; 70:251-258.

15. Budman DR, Tai J, Calabro A, John V. The histone deacetylase inhibitor panobinostat demonstrates marked synergy with conventional chemotherapeutic agents in human ovarian cancer cell lines. Invest New Drugs. 2011; 29:1224-1229.

16. Galli M, Salmoiraghi S, Golay J, Gozzini A, Crippa C, Pescosta N, Rambaldi A. A phase II multiple dose clinical trial of histone deacetylase inhibitor ITF2357 in patients with relapsed or progressive multiple myeloma. Ann Hematol. 2009; 89:185-190.

17. Wang $\mathrm{H}, \mathrm{Yu} \mathrm{N}$, Chen D, et al. Discovery of (2E)-3-\{2butyl-1-[2-(diethylamino)ethyl]-1H-benzimidazol-5-yl $\}$ N-hydroxyacrylami de (SB939), an orally active histone deacetylase inhibitor with a superior preclinical profile. J Med Chem. 2011; 54:4694-4720.

18. Phiel CJ, Zhang F, Huang EY, Guenther MG, Lazar MA, Klein PS. Histone deacetylase is a direct target of valproic acid, a potent anticonvulsant, mood stabilizer, and teratogen. J Biol Chem. 2001; 276:36734-36741.

19. Piekarz RL, Frye AR, Wright JJ, Steinberg SM, Liewehr DJ, Rosing DR, Sachdev V, Fojo T, Bates SE. Cardiac studies in patients treated with depsipeptide, FK228, in a Phase II trial for T-cell lymphoma. Clin Cancer Res. 2006; 12:3762-3773.

20. Bose R, Holbert MA, Pickin KA, Cole PA. Protein tyrosine kinase-substrate interactions. Curr Opin Struct Biol. 2006; 16:668-675.

21. Manning G, Whyte DB, Martinez R, Hunter T, Sudarsanam S. The protein kinase complement of the human genome. Science. 2002; 298:1912-1934.

22. Cowan-Jacob SW. Structural biology of protein tyrosine kinases. Cell Mol Life Sci. 2006; 63:2608-2625.

23. Bikker JA, Brooijmans N, Wissner A, Mansour TS. Kinase domain mutations in cancer: Implications for small molecule drug design strategies. J Med Chem. 2009; 52:1493-1509.

24. Li E, Hristova K. Role of receptor tyrosine kinase transmembrane domains in cell signaling and human pathologies. Biochemistry. 2006; 45:6241-6251.

25. Hope TA, Leboit PE, High WA, Fu Y, Brasch RC. Evaluation of imatinib mesylate as a possible treatment for nephrogenic systemic fibrosis in a rat model. Magn Reson Imaging. 2013; 31:139-144.

26. Shen L, Li Z, Shen S, Niu X, Yu Y, Li Z, Liao M, Chen $\mathrm{Z}, \mathrm{Lu} \mathrm{S}$. The synergistic effect of EGFR tyrosine kinase inhibitor gefitinib in combination with aromatase inhibitor anastrozole in non-small cell lung cancer cell lines. Lung Cancer. 2012; 78:193-200.

27. Moore MJ, Goldstein D, Hamm J, et al. Erlotinib plus gemcitabine compared with gemcitabine alone in patients with advanced pancreatic cancer: A Phase III trial of the national cancer institute of canada clinical trials group. J Clin Oncol. 2007; 25:1960-1966.

28. Abou-Alfa GK, Schwartz L, Ricci S, Amadori D, Santoro A, Figer A, De Greve J, Douillard JY, Lathia C, Schwartz B, Taylor I, Moscovici M, Saltz LB. Phase II study of sorafenib in patients with advanced hepatocellular carcinoma. J Clin Oncol. 2006; 24:4293-4300.

29. Roskoski R Jr. VEGF receptor protein-tyrosine kinases: Structure and regulation. Biochem Biophys Res Commun. 2008; 375:287-291.

30. Copland M, Hamilton A, Elrick LJ, Baird JW, Allan EK,
Jordanides N, Barow M, Mountford JC, Holyoake TL. Dasatinib (BMS-354825) targets an earlier progenitor population than imatinib in primary CML but does not eliminate the quiescent fraction. Blood. 2006; 107:45324539.

31. Weisberg E, Manley P, Mestan J, Cowan Jacob S, Ray A, Griffin JD. AMN107 (nilotinib): A novel and selective inhibitor of BCR-ABL. Br J Cancer. 2006; 94:17651769.

32. Finn RS, Gagnon R, Di Leo A, Press MF, Arbushites M, Koehler M. Prognostic and predictive value of HER2 extracellular domain in metastatic breast cancer treated with lapatinib and paclitaxel in a randomized phase III study. J Clin Oncol. 2009; 27:5552-5558.

33. Santoni M, Conti A, Massari F, Arnaldi G, Iacovelli R, Rizzo M, De Giorgi U, Trementino L, Procopio G, Tortora G, Cascinu S. Treatment-related fatigue with sorafenib, sunitinib and pazopanib in patients with advanced solid tumors: An up-to-date review and meta-analysis of clinical trials. Int J Cancer. 2015; 136:1-10.

34. Hynes NE, Lane HA. ERBB receptors and cancer: The complexity of targeted inhibitors. Nat Rev Cancer. 2005; 5:341-354

35. Cai X, Zhai HX, Wang J, Forrester J, Qu H, Yin L, Lai CJ, Bao R, Qian C. Discovery of 7-(4-(3-Ethynylphenylamino)7-methoxyquinazolin-6-yloxy)-N-hydroxyheptanamide (CUDC-101) as a Potent Multi-Acting HDAC, EGFR, and HER2 Inhibitor for the Treatment of Cancer. J Med Chem. 2010; 53:2000-2009.

36. Lai CJ, Bao R, Tao X, et al. CUDC-101, a multitargeted inhibitor of histone deacetylase, epidermal growth factor receptor, and human epidermal growth factor receptor 2, exerts potent anticancer activity. Cancer Res. 2010; 70:3647-3656.

37. Mahboobi S, Sellmer A, Winkler M, Eichhorn E, Pongratz H, Ciossek T, Baer T, Maier T, Beckers T. Novel chimeric histone deacetylase inhibitors: A series of lapatinib hybrides as potent inhibitors of epidermal growth factor receptor (EGFR), human epidermal growth factor receptor 2 (HER2), and histone deacetylase activity. J Med Chem. 2010; 53:8546-8555.

38. Mahboobi S, Dove S, Sellmer A, Winkler M, Eichhom E, PongraTz E, Ciossek T, Baer T, Maier T, Beckers $\mathrm{T}$. Design of chimeric histone deacetylase and tyrosine kinase inhibitors: A series of imatinib hybrides as potent inhibitors of wild-type and mutant BCR-ABL, PDGF-R $\beta$, and histone deacetylases. J Med Chem. 2009; 52:22652279.

39. Zuo M, Zheng YW, Lu SM, Li Y, Zhang SQ. Synthesis and biological evaluation of $\mathrm{N}$-aryl salicylamides with a hydroxamic acid moiety at 5-position as novel HDACEGFR dual inhibitors. Bioorg Med Chem. 2012; 20:44054412.

40. Beckers T, Mahboobi S, Sellmer A, et al. Chimerically designed HDAC and tyrosine kinase inhibitors. A series of erlotinib hybrids as dual-selective inhibitors of EGFR, HER2 and histone deacetylases. MedChemComm. 2012; 3:829-835.

41. Zhang X, Su M, Chen Y, Li J, Lu W. The design and synthesis of a new class of RTK/HDAC dual-targeted inhibitors. Molecules. 2013; 18:6491-6503.

(Received January 12 2015; Revised March 10, 2015; Re-revised May 9, 2015; Accepted May 19, 2015) 